\title{
Decolourization of paprika dye effluent with hydrogen peroxide produced by glucose oxidase
}

\author{
IDALINA GONÇALVES, CARLA SILVA \& ARTUR CAVACO-PAULO \\ Department of Textile Engineering, University of Minho, Guimarães, Portugal
}

\begin{abstract}
Hydrogen peroxide was produced from bran by a two-step process using cellulase/xylanase and glucose oxidase, sequentially. The decolourization efficiency of the produced reagent was tested using paprika oil dye (effluent from industrial source) and high levels of colour removal (96\%) were achieved after saponification pre-treatment and hydrogen peroxide application. The method is economically and environmentally advantageous since lower energy and chemical input are needed and wastewater pollution is considerably reduced. At the same time, the utilization of waste materials was successfully achieved.
\end{abstract}

Keywords: effluent, paprika oil, dye, glucose oxidase, hydrogen peroxide, decolourization.

\section{Introduction}

Biotechnological systems for exploiting renewable raw materials have been developed for the textile industry in order to discover efficient, environmentally friendly processes that require less energy and water (Gübitz \& Cavaco-Paulo 2001; Nierstrasz \& Cavaco-Paulo 2010). Several enzymes have been applied in textile treatments, such as amylases for starch-size removal, cellulases and hemicellulases (xylanase) for changing the polymerization degree of desized cotton fabrics and laccases to remove colour from dyeing effluents (Campos et al. 2001; Csiszár et al. 2001; Kumar 2007). Glucose oxidase ( $\beta$-Dglucose:oxygen 1-oxidoreductase, EC 1.1.3.4) is a flavoenzyme that catalyses the oxidation of $\beta-\mathrm{D}$ glucose to gluconic acid using molecular oxygen as an electron acceptor with simultaneous production of hydrogen peroxide (Wu et al. 2005; Bankar et al. 2009). The resulting hydrogen peroxide is an environmentally acceptable oxidizing agent that can be used, for example, in textile industry to promote the whiteness of fabrics (López \& Cavaco-Paulo 2008; Tzanov et al. 2002) and treat strongly coloured wastewaters. The latter are conventionally treated by application of membranes, physico-chemical and advanced oxidizing processes (Hung et al. 2005). However, chemo-enzymatic treatments are being studied as an alternative, environmentally friendly approach (Karam \& Nicell 1997).

In this work glucose, enzymatically generated from a cellulosic material (bran), was used as the substrate for hydrogen peroxide production by glucose oxidase (GOD). The efficiency of the produced oxidising agent was tested on the decolourization of an industrial effluent, mostly composed by paprika dye, which is frequently used in food, textile, cosmetic and pharmaceutical industries as a natural red dye (Deli et al. 2001).

\section{Materials and methods}

\section{Materials}

The bran used for glucose extraction was obtained from an industrial source as well as the dye effluent (paprika oil) used for decolourization. This dye was composed mainly of carotenoids (capsanthin and capsorubin), responsible for the red colour; glycosides (capsianoside II) and glycolipids (monogalactosyldiacylglycerol). The glucose-oxidase GC199

Correspondence: Artur Cavaco-Paulo, Department of Textile Engineering, University of Minho, 4800-058 Guimarães, Portugal. Tel: +351-253-510271. Fax: +351-253-510293. E-mail: artur@det.uminho.pt. Home page: http://www.det.uminho.pt/acavaco/ 


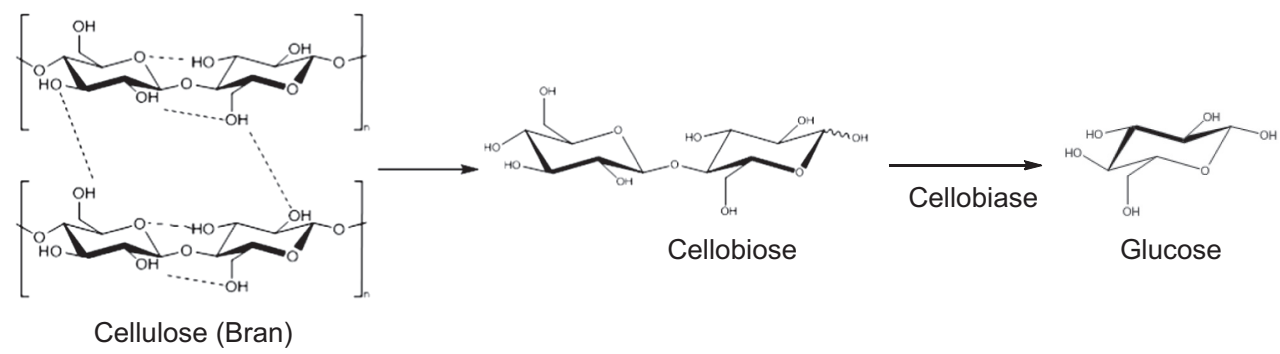

Figure 1. Schematic representation of cellulose hydrolysis and glucose production with Cellulase Multifect CX GC: endoglucanase (1); exoglucanase (2) and cellobiase (Gilbert \& Hazlewood 1993).

from Aspergillus niger (1.500 $\mathrm{U} \mathrm{ml}^{-1}, \mathrm{pH}$ 5.1-5.4, $40-60^{\circ} \mathrm{C}$, with very low catalase activity), cellulase Multifect ${ }^{\circledR}$ CX GC from Trichoderma reesei (3200 U $\left.\mathrm{g}_{\text {protein }}{ }^{-1}, \mathrm{pH} 2.7-5.7,35-70^{\circ} \mathrm{C}\right)$ and xylanase Optimase ${ }^{\circledR}$ CX $255 \mathrm{~L}$ from Trichoderma reesei $(56000$ $\mathrm{ABX}_{\text {protein }}{ }^{-1}$, where ABX means Acid Birchwood, $\left.\mathrm{pH} 4-8,60-80^{\circ} \mathrm{C}\right)$. All other reagents were used as supplied without further purification.

\section{Methods}

Glucose extraction from bran. For glucose extraction from bran, two approaches were followed: enzymatic and acid hydrolysis. For acid hydrolysis, $27 \mathrm{~g}^{-1}$ of bran was incubated with different concentrations of $\mathrm{HCl}(0.5-5 \mathrm{M})$ for $24 \mathrm{~h}$ at room temperature with stirring. For enzymatic hydrolysis, $27 \mathrm{~g} \mathrm{l}^{-1}$ of bran was incubated in $0.01 \mathrm{M}$ acetate buffer at $\mathrm{pH} 5$, with a mixture of $0.05 \%(\mathrm{v} / \mathrm{v})$ cellulase and xylanase for $1 \mathrm{~h}$ at $25^{\circ} \mathrm{C}$ using $100 \mathrm{rpm}$ agitation.

Hydrogen peroxide production. In order to obtain the best conditions for hydrogen peroxide production, several parameters were studied, namely concentration of glucose $\left(2,4\right.$ and $\left.6 \mathrm{~g} \mathrm{l}^{-1}\right)$, ionic strength of acetate buffer (0.01-0.5 M), $\mathrm{pH}$ (4-8), temperature $\left(20,35^{\circ} \mathrm{C}\right)$, incubation time $(30-180 \mathrm{~min})$ and enzyme concentration $\left(0.04,0.1\right.$ and $\left.0.2 \mathrm{U} \mathrm{ml}^{-1}\right)$. The conditions tested were chosen according to the preliminary and published results.

Subsequently, the optimum conditions were followed using $2 \mathrm{~g}^{-1}$ glucose in $0.01 \mathrm{M}$ acetate buffer

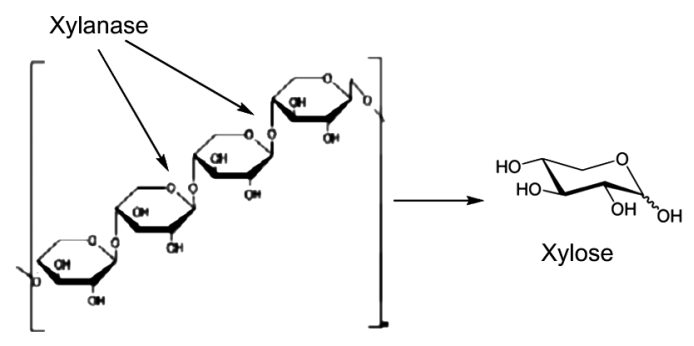

Figure 2. Schematic representation of xylan ( $\beta$-1,4-D-xilopiranosil) hydrolysis by xylanase (Optimase CX 255L) and one possible constituent sugar (Gilbert \& Hazlewood 1993).
$\mathrm{pH}$, with GOD $\left(0.1 \mathrm{U} \mathrm{ml}^{-1}\right)$ for $2 \mathrm{~h}$ at room temperature with $100 \mathrm{rpm}$ agitation.

Dye effluent decolourization. The decolourization of the dye effluent was assessed by following two steps: preliminary chemical decolourization using 50\% (w/v) $\mathrm{NaOH}$ for $15 \mathrm{~min}$ at room temperature with stirring, followed by enzymatic decolourization using $0.5 \mathrm{~g} \mathrm{l}^{-1}$ hydrogen peroxide (60:40 - hydrogen peroxide:dye, by vol) produced by glucose oxidase action for $24 \mathrm{~h}$ at $90^{\circ} \mathrm{C}, \mathrm{pH} 11$ using $100 \mathrm{rpm}$ agitation.

Determination of glucose concentration. The concentration of glucose extracted from bran was determined by using the neocuproine method (Cavaco-Paulo \& Almeida 1996), which is based on the alkaline reduction of the complex neocuproine copper II (yellow solution) into neocuproine copper I (orange solution). The colour change after boiling the sample was monitored at $475 \mathrm{~nm}$ using a Helios Gamma UV-Vis spectrophotometer (Thermo Scientific, Waltham, MA, USA). The calibration curve was plotted using standard glucose samples $\left(1-6 \mathrm{~g}^{-1}\right)$.

Determination of hydrogen peroxide. The concentration of hydrogen peroxide produced by enzymatic action was determined by redox titration using

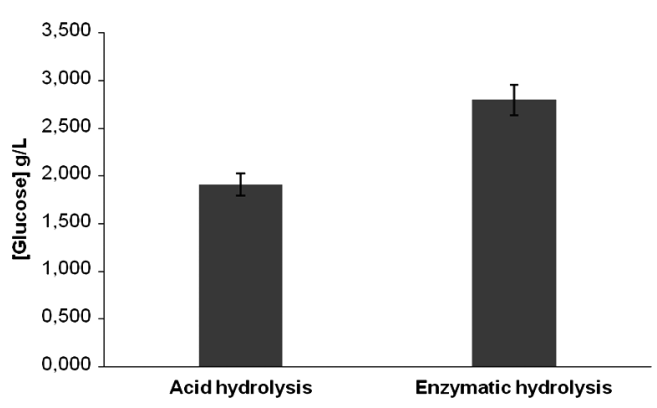

Figure 3. Generation of glucose from bran $\left(27 \mathrm{~g} \mathrm{l}^{-1}\right)$ using acid ( $\mathrm{HCl} 5 \mathrm{M}$ during $24 \mathrm{~h}$ of incubation at room temperature with stirring agitation) and enzymatic hydrolysis (cellulase/xylanase $0.05 \%(\mathrm{v} / \mathrm{v})$ during $2 \mathrm{~h}$ of incubation at $25^{\circ} \mathrm{C}$ in $0.01 \mathrm{M}$ sodium acetate buffer $\mathrm{pH} 5$ at $100 \mathrm{rpm}$ ). 


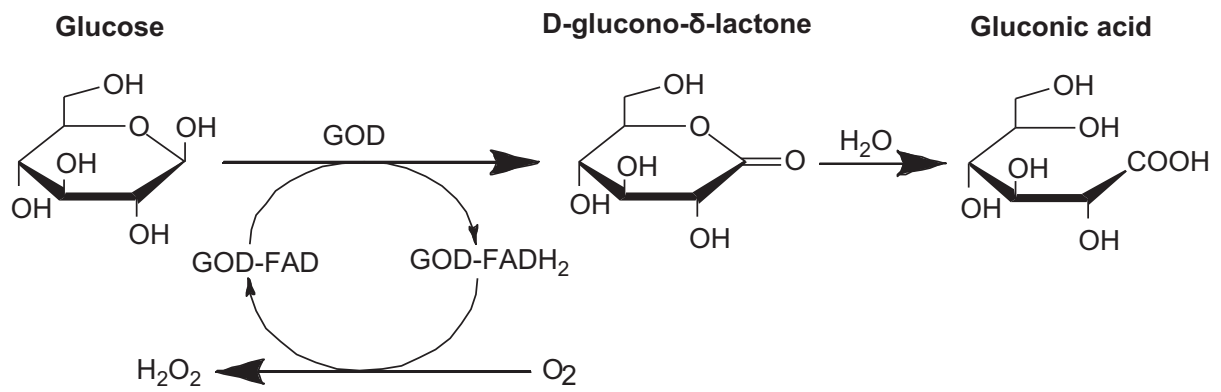

Figure 4. Schematic representation of hydrogen peroxide production with glucose oxidase (Simpson et al. 2007).

potassium permanganate $(0.001 \mathrm{M})$ as titrating solution (Tzanov et al. 2002).

Decolourization quantification. The percentage of dye effluent decolourization was determined using a Helios Gamma UV-Vis spectrophotometer (Thermo Scientific, Waltham, MA, USA) at $450 \mathrm{~nm}$ and calculated as follows:

$$
\% \text { decolorization }=\left[\frac{\left(A b s_{\text {initial }}-A b s_{\text {final }}\right)}{A b s_{\text {initial }}}\right] \times 100
$$

\section{Results}

\section{Glucose extraction from bran}

Cellulases and xylanases encompass a collection of enzymes whose primary function is to hydrolyse $\beta$ 1,4 -glycosidic linkages in the structural polysaccharides, cellulose and hemicellulose (where the major component is xylan), converting them into their constituent sugars (Figures 1 and 2) (Gilbert \& Hazlewood 1993). The results demonstrated that the cellulase/xylanase mixture was more efficient than acid hydrolysis. After acid hydrolysis of bran $\left(27 \mathrm{~g} \mathrm{l}^{-1}\right)$ with $5 \mathrm{M} \mathrm{HCl}$ for $24 \mathrm{~h}$ at $20^{\circ} \mathrm{C}$, the highest glucose concentration achieved was approximately $2 \mathrm{~g} \mathrm{1}^{-1}$, representing $7 \%$ of raw product conversion into glucose. The best conditions for enzymatic hydrolysis $(0.05 \% \mathrm{v} / \mathrm{v}$ enzyme mixture of cellulase and xylanase at $25^{\circ} \mathrm{C}$ for $2 \mathrm{~h}$ ) produced approximately $3 \mathrm{~g} \mathrm{l}^{-1}$ of glucose, corresponding to $11 \%$ of bran conversion (Figure 3). Dilute acids can lead to a limited hydrolysis called pre-hydrolysis. This consists in the hydrolysis of the accessible hemicellulosic fraction, leaving the cellulose and lignin fractions almost unaltered (Herrera et al. 2004). The temperature chosen for acid hydrolysis was much lower $\left(20^{\circ} \mathrm{C}\right)$ than reported in the literature $\left(100^{\circ} \mathrm{C}\right)$, since low energy consumption was required. The enzymatic conversion might have been limited by inhibition of the cellulase by the end-product glucose, hindering further degradation of the bran.

\section{Hydrogen peroxide production by GOD}

The GOD reaction involves a reductive and an oxidative step. In the first step, it catalyses the oxidation of $\beta$-D-glucose to D-glucono- $\delta$-lactone (which is non-enzymatically hydrolysed to gluconic acid) reducing the flavin adenine dinucleotide (FAD) ring of GOD to $\mathrm{FADH}_{2}$. In the second step, reduced GOD is reoxidised with oxygen to yield hydrogen peroxide (Figure 4) (Bankar et al. 2009). The production of hydrogen peroxide by GOD was optimized for $\mathrm{pH}$, enzyme concentration, temperature, incubation time, glucose concentration and buffer ionic strength. The highest level of hydrogen peroxide $(0.5 \mathrm{~g} / \mathrm{L})$ corresponded to $25 \%$ of glucose conversion. This limited conversion may be due to
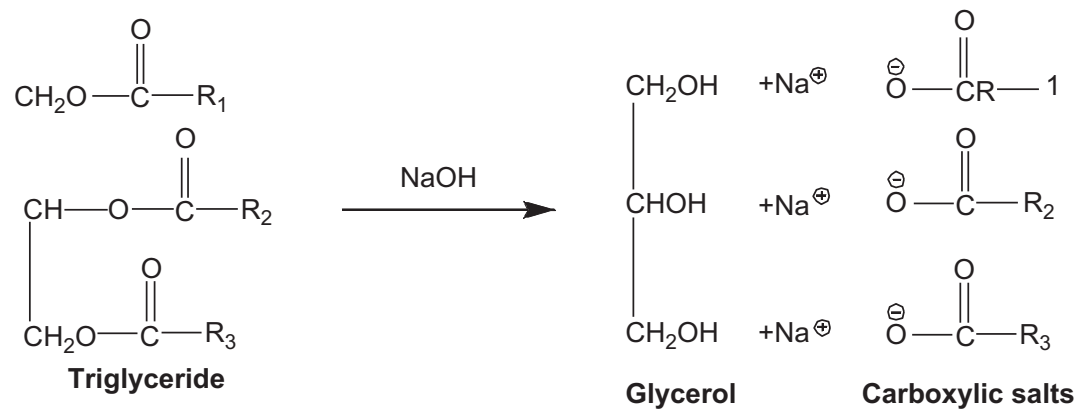

Figure 5. Schematic representation of saponification of paprika oil dye by sodium hydroxide (sludge formation) (Farinha 2009). 


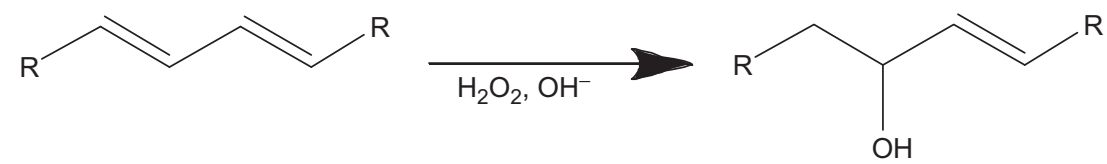

Figure 6. Schematic representation of paprika oil dye decolourization by hydrogen peroxide action (Carey 2003).

the presence of residual compounds (polysaccharides, proteins, fats and mineral salts) arising from glucose release, which could restrict hydrogen peroxide production. As the optimum temperature of glucose oxidase is $50^{\circ} \mathrm{C}$, it was expected that a higher level of conversion would be obtained at $35^{\circ} \mathrm{C}$ than at $20^{\circ} \mathrm{C}$. However, the results showed higher hydrogen peroxide production at the lower temperature, which might also reflect the presence of inhibitors.

\section{Decolourization of paprika oil}

The enzymatically produced hydrogen peroxide was tested on the decolourization of paprika oil. Since this oily dye has a significant lipid fraction that could hinder colour removal, it was saponified as a pretreatment to improve decolourization. Paprika oil without any pre-treatment was used as a control.

The colour of paprika oil without any pretreatment, diluted 80 -fold in $0.1 \mathrm{M}$ acetate buffer, was reduced $55 \%$ after hydrogen peroxide addition $\left(60 \% \mathrm{v} / \mathrm{v}\right.$, at $90^{\circ} \mathrm{C}, \mathrm{pH} 11$ for $24 \mathrm{~h}$, with an agitation of $100 \mathrm{rpm}$ ). After saponification using $50 \% \mathrm{w} / \mathrm{v}$ $\mathrm{NaOH}$ (dye: $\mathrm{NaOH}, 1: 5$, by vol.) for $15 \mathrm{~min}$ at $100 \mathrm{rpm}, 40 \%$ of the initial dye $\left(\mathrm{Abs}_{450 \mathrm{~nm}}=3.159\right)$ was converted into sludge (Figures 5 and $7 \mathrm{~A}$ ) that was removed by filtration; hydrogen peroxide was then applied to the remaining orange solution $\left(\mathrm{Abs}_{450 \mathrm{~nm}}=2.451\right)$ (Figure 7B). Even though the

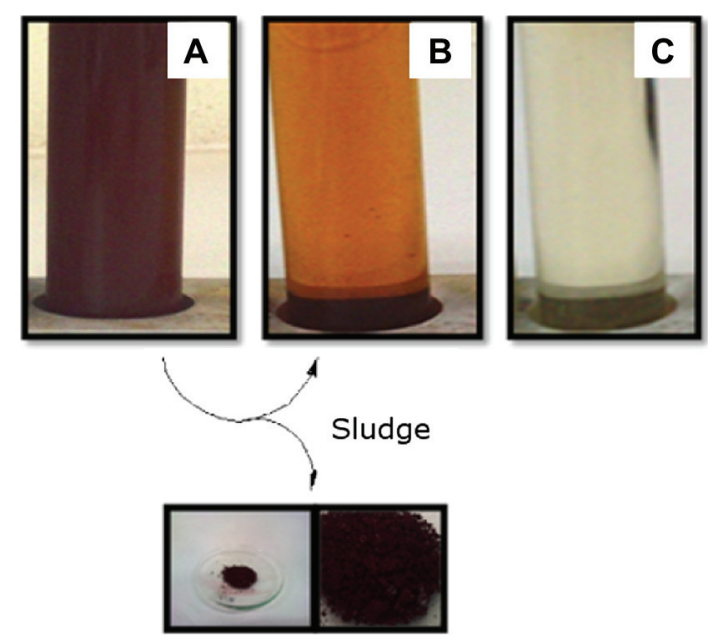

Figure 7. Different stages of paprika oil dye decolourization; (A) Initial dye colour; (B) dye colour after sludge removal; (C) dye colour after decolourization with hydrogen peroxide; the sludge after saponification between stages $\mathrm{A}$ and $\mathrm{B}$ is also shown. composition of the sludge needs to be examined, it may have application as an antimicrobial product, due to the high level of carotenoids present, or as soap for specific applications. The results show that after saponification, $96 \%$ of the colour was removed by hydrogen peroxide, reaching an almost uncoloured solution $\left(\mathrm{Abs}_{450 \mathrm{~nm}}=0.091\right.$ ) (Figure 7C).

As paprika oil has a high content of carotenoids with conjugated double bonds, a decrease in colour intensity could be obtained by disruption of these bonds with the formation of unpaired linkages (Carey 2003). Based on this assumption, the hydrogen peroxide was applied at $90^{\circ} \mathrm{C}$ to generate hydroxyl ${ }^{25 \mathrm{CF}}$ radicals, which can oxidize and disrupt the double bonds, eliminating the natural colour (Figure 6). However, the resulting decolourization products, like aromatic amines, should be taken into consideration, since their presence at wastewaters will increase toxicity. Polymerization of these aromatic amines would be possible using laccases as specific catalysts (Zille et al. 2005). However, after analysis of the costs of reagents (enzymes, $\mathrm{NaOH}$ and others), energy input, time and water consumption, lower costs were found for the process where saponification pre-treatment was included. Based on the current costs for a food company to treat paprika waste, the process described here, incorporating enzymatic production of hydrogen peroxide and saponification as a pre-treatment, is 5-times lower (data not shown). Thus, despite the significant cost of the enzyme, the process is more economic than current industrial practice, involving physico-chemical methods.

\section{Acknowledgements}

The authors would like to acknowledge the industrial source for the bran and dye supply.

Declaration of interest: The authors report no conflicts of interest. The authors alone are responsible for the content and writing of the article. Carla Silva would like to acknowledge the Portuguese Fundação para a Ciência e a Tecnologia (FCT) for funding under the scholarship SFRH/BPD/46515/ 2008. 


\section{References}

Bankar SB, Bule MV, Singhal RS, Ananthanarayan L. 2009. Glucose oxidase - An overview. Biotechnol Adv 27:489-501.

Campos R, Kandelbauer A, Robra KH, Cavaco-Paulo A, Gübitz GM. 2001. Indigo degradation with purified laccases from trametes hirsuta and Sclerotium rolfsii. J Biotechnol 89: 131-139.

Carey F. 2003. Organic Chemistry. New York: Mc-Graw Hill Companies, Inc.

Cavaco-Paulo A, Almeida L. 1996. Kinetic parameters measured during cellulase processing of cotton. J Textil Inst 87:227-233.

Csiszár E, Urbánszki K, Szakács G. 2001. Biotreatment of desized cotton fabric by commercial cellulase and xylanase enzymes. Journal of Molecular Catalysis B: Enzymatic 11:1065-1072.

Deli J, Molnár P, Matus Z, Tóth G. 2001. Carotenoid composition in the fruits of red paprika (capsicum annuum var. lycopersiciforme rubrum) during ripening; biosynthesis of carotenoids in red paprika. J Agr Food Chem 49:1517-1523.

Farinha NHM. 2009. Metodologias alternativas para determinação do teor de esteróis em azeite Master Thesis Departamento de Química: Universidade de Aveiro Portugal.

Gilbert HJ, Hazlewood GP. 1993. Bacterial cellulases and xylanases. J Gen Microbiol 139:187-194.

Gübitz GM, Cavaco-Paulo A. 2001. Biotechnology in the textile industry - perspectives for the new millennium. J Biotechnol 89:89-90.

Herrera A, Téllez-Luis SJ, González-Cabriales JJ, Ramírez JA, Vázquez M. 2004. Effect of the hydrochloric acid concentration on the hydrolysis of sorghum straw at atmospheric pressure. J Food Eng 63:103-109.

Karam J, Nicell JA. 1997. Potential applications of enzymes in waste treatment. J Chem Tech Biotechnol 69:141-153.

Kumar GVNS. 2007. Scope of biotechnology in textiles. J Textil Assoc: 263-266.

López C, Cavaco-Paulo A. 2008. In-situ enzymatic generation of hydrogen peroxide for bleaching purposes. Engineering in Life Sciences 8:315-323.

Nierstrasz V, Cavaco-Paulo A. 2010. Advances in textile biotechnology. Cambridge: Woodhead Publishing Ltd.

Simpson C, Jordaan J, Gardiner NS, Whiteley C. 2007. Isolation, purification and characterization of a novel glucose oxidase from penicillium sp. CBS 120262 optimally active at neutral pH. Protein Expr Purif 51:260-266.

Tzanov T, Costa SA, Gübitz GM, Cavaco-Paulo A. 2002. Hydrogen peroxide generation with immobilized glucose oxidase for textile bleaching. J Biotechnol 93:87-94.

Wu M, Lin Z, Schäferling M, Dürkop A, Wolfbeis OS. 2005. Fluorescence imaging of the activity of glucose oxidase using a hydrogen-peroxide-sensitive europium probe. Anal Biochem 340:66-73.

Yung-Tse H, Eduard B, Thomas B. 2005. Treatment of Textile Wastes In: Waste Treatment in the Process Industries: CRC Press. pp. 363-398.

Zille A, Gornacka B, Rehorek A, Cavaco-Paulo A. 2005. Degradation of azo dyes by trametes villosa laccase over long periods of oxidative conditions. Appl Environ Microbiol 71: $6711-6718$ 